\title{
Breast Fibroglandular Tissue
}

National Cancer Institute

\section{Source}

National Cancer Institute. Breast Fibroglandular Tissue. NCI Thesaurus. Code C114467.

Breast tissue that contains glandular epithelial and fibrous tissue. 